\title{
'ONE CHIEF, ONE VOTE': THE REVIVAL OF TRADITIONAL AUTHORITIES IN POST-APARTHEID SOUTH AFRICA
}

\author{
INEKE VAN KeSSEL AND BARBARA OOMEN
}

\begin{abstract}
During the apartheid era, chiefs were maligned as puppets of bantustan rule. In ANC-related circles, it was widely assumed that chieftaincy would not survive in the post apartheid era. But the institution of traditional leadership has proved highly flexible. Rather than being phased out as relics of pre-modern times, chiefs are re-asserting themselves in the new South Africa. Chiefs have survived throughout this century with a strategy of shifting alliances. Towards the end of the 1980 s, chiefs were re-orienting themselves towards the ANC, rightly perceived as the new ruling party-in-waiting. Combining the resources of tradition with a discourse of liberation politics and development, they were able to explain constitutional and other legal guarantees for the position of traditional leaders and their representations in the local, provincial and national administration. For its part, the ANC had an interest in wooing chiefs to its side in order to prevent the emergence of a conservative alliance where traditional leaders could join forces with the bantustan elites. The article analyses these developments, discusses the main themes of debate and concludes with a brief case study of chieftaincy issues in the Northern Transvaal.
\end{abstract}

ABOUT 40 PERCENT of the people of South Africa and 17 percent of its territory are ruled by traditional authorities. These 17 million subjects of chiefly rule are governed by about 800 traditional leaders. ${ }^{1}$ Like almost everything else regarding chieftaincy, these figures are disputed. Depending on one's definition of 'traditional leader', their numbers could multiply to perhaps 10,000 . Rather than being phased out as relics of pre-modern times, chiefs are re-asserting themselves in post-apartheid South Africa. Nor are they satisfied with a ceremonial role as guardians of African custom. They demanded and obtained constitutional guarantees for their position and their representation in the local, provincial and national administration. In view of South Africa's history, this is a surprising outcome of a long liberation struggle.

The first part of this article is a brief survey of the changing perspectives on chieftaincy within the African National Congress and its allied

Ineke van Kessel is a researcher with the African Studies Centre, Leiden, The Netherlands. Barbara Oomen is associated with the Van Vollenhoven Institute of Leiden University, where she is preparing a doctoral thesis on traditional authorities and customary law in South Africa.

1. Figures provided in 1996 by the Department of Constitutional Development. 
movements. Secondly, we describe the position of traditional authorities during the present transition period (1994-1999), and the main themes of discussion in the constitutional negotiations. Is the revival of traditional authorities likely to be a lasting phenomenon or just a passing phase? The last part presents a case study in the Northern Province (formerly the Northern Transvaal), a province with a high proportion of chiefs since it incorporates three former bantustans. One constant theme over time is that of shifting alliances: chiefs often align themselves, whether wholeheartedly or for tactical reasons, with the powers that seem to offer the best chances of safeguarding their positions. This strategy is of course not the exclusive preserve of traditional leaders. But being traditional leaders, chiefs have a resource which is not so readily available to commoners: tradition. What is a tradition? Webster's dictionary gives the following definition: 'a cultural continuity transmitted in the form of social attitudes, beliefs, principles and conventions of behaviour etc, deriving from past experience and helping to shape the present'. In the context of this article, 'helping to shape the present' is the crucial element.

In post-apartheid South Africa, numerous chiefs have become adept in combining the resource of tradition with appeals to western models and the discourse of liberation politics. Thus, chiefs project themselves as guardians of African custom, but simultaneously as pioneers of rural development. They campaign for the establishment of a House of Traditional Leaders based on the model of the British House of Lords and demand simultaneously that their representation in this House ought to be based on the democratic principles advocated by liberation movements. The principle of 'One Man, One Vote', after having gone through the non-sexist phase of 'One Person, One Vote', is being transformed by some traditional leaders into the 'time-tested' principle of 'One Chief, One Vote'.

\section{Chiefs and liberation politics}

Among the founding members of the African National Congress were a considerable number of chiefs. ${ }^{2}$ Upon the formation of the ANC in 1912, an Upper House was created to accommodate traditional leaders who joined the organization. In its early days, the ANC represented the concerns of a small professional middle class which maintained close links with the African aristocracy, the rural chieftaincy. South Africa's industrial revolution in the 1940s and 1950s transformed the ANC into a mass movement with a following mainly located in the main industrial centres. From the second half of the 1940 s, the ANC went through a radicalization process which was inspired both by its growing working class base and by the coming to power of the National Party in the 1948 elections. During

2. At the time of its formation in 1912, the organization was known as the South African Native National Congress. 
the 1950s, the National Party government engaged in a profound restructuring of rural society, which would fundamentally alter the relationship between the ANC and the rural aristocracy. The African reserves in the countryside played a crucial role in the governments' efforts to establish tighter control over African labour. Labour bureaux regulated the supply of labour to the mines, commercial agriculture and industry. Labour mobility was further controlled by a tightening of the pass laws. In the African villages, the administration of the pass book and the running of the labour bureaux, where permits had to be annually renewed, were the responsibility of the chief. Local government in rural areas was reshaped by the 1951 Bantu Authorities Act, which aimed at self rule and ultimately 'independence' for the bantustans. Power rested with a hierarchy of compliant chiefs, who were made utterly dependent on the patronage of the Department of Native Affairs. Chiefs were no longer accountable to their subjects, but to the Department. Their powers were increased while their legitimacy was being eroded. Adding to their unpopularity was their role in the implementation of the policies of agricultural betterment, which involved cattle culling and land demarcation.

Not all chiefs were willingly incorporated in this new dispensation. During the 1950s and early 1960s, South Africa experienced a series of rural revolts, ranging from Zoutpansberg in the far north to Mpondo-land and Tembu-land in the Eastern Cape. Paramount Chief Sabata Dalindyebo headed the revolt in Tembu-land. He was sidelined and later deposed by his rival Kaiser Matanzima, who as the more compliant chief profited from government patronage to become prime minister and subsequently president of the Transkei. ${ }^{3}$ Later Dalindyebo went into exile where he linked up with the ANC. He died in exile, but his reburial in the Transkei in 1989 turned into a massive demonstration of support for the ANC in the countryside. In the Northern Transvaal, the acting paramount chief of Sekhukhuneland, Morwamoche Sekhukhune, and a majority of his people actively opposed the Bantu Authorities system. The paramount chief was deposed and sent into internal exile. ${ }^{4}$

The imposition of Bantu Authorities not only changed the relationship between the chief and his subjects. It also upset the balance within the 'tribal' hierarchy. In Sekhukhuneland, and in numerous other regions, the Native Affairs Department undermined the opposition by breaking the power of the paramountcy. Subordinate headmen were offered recognition as chiefs if they accepted the establishment of Tribal Authorities. This scheme resulted in a proliferation of chieftaincies. Initially,

3. T. Lodge, Black Politics in South Africa since 1945 (Ravan Press, Johannesburg, 1983), ch. 11 .

4. P. Delius, 'Sebatakgomo: Migrant Organization, the ANC and the Sekhukhune revolt', Fournal of Southern African Studies, 15, 4 (1989), pp. 581-615; P. Delius, 'Migrants, comrades and rural revolt: Sekhukhuneland 1950-1987', Transformation, 13 (1990), pp. 2-26. 
Sekhukhuneland counted nine chieftaincies, but by the mid 1970s more than 50 chiefs had been officially recognized. ${ }^{5}$ The paramountcy had been abolished. The doubtful origins of many chiefs served to further weaken their legitimacy, as many 'chiefs' were considered to be only 'headmen' who had usurped chiefly powers. On the other hand, this history of resistance on the part of a number of chiefs could be drawn upon to demonstrate the role played by traditional leaders in the fight against white domination. When, in the late 1980 s, chiefs were seeking to secure their future in a post apartheid state by linking up with the ANC, they constructed a sense of historical continuity by focusing on these examples of resistance rather than the mainstream pattern of chiefly compliance.

Until about 1950, the ANC's organizational strategy aimed at establishing rural branches through chiefs. This approach limited its capacity to mobilize a mass constituency, as popular grievances were accumulating against chiefs. In the eyes of many, the office had been corrupted by the control exercised by the Native Affairs Department. The ANC's rural strategy had reached the end of its potential by the early 1950s. With the introduction of Bantu Authorities in the 1950s, state recognition had become more vital for the chieftaincy than popular support. Chiefs had become civil servants, to be hired, fired, paid and, if necessary, created by the government. If they were lucky enough to be designated a member of a homeland parliament they would also receive a car and some other perks. The Bantu Authorities Act had further upset the customary system of checks and balances. Chiefs came to be seen more as coercive agents of the bantustan regimes.

However, chiefs continued to play a role in the ANC, as demonstrated by chief Albert Luthuli, who was elected ANC president in 1952. Luthuli was a relatively minor Zulu chief, whose memory can nowadays be exploited for a double purpose: to stress the historical continuity of the role of chiefs in liberation politics, but also to establish the credentials of the $\mathrm{ANC}$ as a movement with a firm base among the Zulu people, an important asset for the ANC when contesting the monopolization of Zulu tradition by Inkatha. But by the early 1960 s, chiefs were no longer perceived as potential allies in the liberation struggle. The ANC had been banned in 1960 and in exile concentrated on rebuilding the movement and enlisting international support for the anti-apartheid struggle. During the 1960s, the ANC remained hopeful about the revolutionary potential of the bantustans, even though the rural revolts had been crushed by severe repression. A strategic review, undertaken after the Soweto rising of 1976, shifted the thrust of ANC strategic thinking towards the urban areas. The road to power, it was now believed, was not through rural

5. C. V. Bothma, 'The political structure of the Pedi of Sekhukhuneland', African Studies, 35, 3-4 (1976), p. 179. 
rebellion, but through urban guerrilla activity in combination with indefinite strikes and mass risings.

The ANC had no clear cut policy on chiefs. Although the institution as such was never officially denounced by the liberation movement, many leading figures in the ANC assumed that chieftaincy would either die of its own accord or otherwise would be abolished. Govan Mbeki, writing on the peasant revolts of the 1950s, questioned the role of chiefs in the industrial age. 'If the Africans have had chiefs, it was because all human societies have had them at one stage or another. But when a people have developed to a stage which discards chieftainship, when their social development contradicts the need for such an institution, then to force it on them is not liberation but enslavement.' 6 Writing a quarter of a century later, another leading ANC intellectual was more straightforward: 'Backward tribal and other relationships such as the role of the chiefs in such situations, will be replaced by democratic institutions founded on the organs of people's power'.?

\section{Chiefs in the 1980s: enemies of the liberation struggle}

These pronouncements of ANC leaders in prison or in exile were in line with the prevailing opinions among leaders of the internally-based antiapartheid opposition. During the $1980 \mathrm{~s}$, a multitude of organizations found common ground under the umbrella of the United Democratic Front (UDF), which functioned more or less as the internal ally of the banned liberation movement. Chiefs were on the margins of the UDF's concerns. As with the ANC in the preceding decades, most UDF campaigns were geared towards urban areas. Its rural affiliates consisted mainly of youth organizations, led by students at secondary and tertiary schools. Attempts to recruit migrant workers were not pursued with much vigour. Generational cleavages in the liberation movement, a well-known feature of urban resistance, became even more pronounced in the rural setting, where power was wielded by chiefs, teachers and elders. Grievances against the authoritarian rule and frequent misappropriation by the chief were by no means limited to youth, but the youth movement, with few exceptions, did not succeed in building a broad alliance around their campaigns against chieftaincy. Radicalized youth movements often acted in isolation.

In the Northern Transvaal, generational conflict manifested itself in a dramatic spate of witch hunts in the second half of the 1980s. Convinced that they needed to put their own house in order before they would be able to effectively confront the apartheid state, youth activists set out to identify the forces of evil which were supposedly subverting their struggle. In

6. Govan Mbeki, The Peasants Revolt (1964; Defence and Aid Fund, London, 1984), p. 47. 7. Mzala, Gatsha Buthelezi: Chief with a double agenda (Zed Books, London, 1988), p. 224. 
these witch hunts, youths often bypassed the village hierarchies of chiefs, elders and dingaka (traditional healers) and proceeded to identify the culprits and subsequently to execute them, frequently by putting a car tyre doused in petrol around the neck of the victims and burning them to death. This was not only an 'un-traditional' method of execution, an imitation of the necklacing of suspected informers in the townships, it also meant that youths were usurping the powers of both secular and spiritual authorities in the village. By upsetting the generational order, these anti-witchcraft movements served to alienate many adults from radical politics. ${ }^{8}$ But even before the escalation of youth militancy, chiefly powers were being eroded.

The abolition of the pass laws in 1986 meant that migrants no longer had to present themselves at the chief's office in their home village. Chiefs lost their income from registration fees and their control over the movements of their subjects. Recalcitrant villagers could no more be punished by withholding labour permits and travel documents. It also meant that the chiefs no longer had the opportunity to collect arrears from their migrant subjects. Faced with diminishing control, chiefs frequently reacted by imposing new taxes to make up for the lost revenue. One way of increasing their income was to seize control over the boreholes which were provided in drought relief programmes. People were then made to pay for the water.

There is an interesting parallel between the changing position of the Black Local Authorities in the administration of the townships and the dismantling of chieftaincies during the 1980s. Both experienced an important loss of revenue: in the case of the townships, privatization caused the loss of revenue from the monopoly on liquor sales and sorghum beer. The resulting increase of financial burdens on the inhabitants was an important ingredient in the build-up of both the urban and the rural crisis. The dilemmas of the new black township authorities, whose position has been characterized as one of 'responsibility without power', have been the subject of several studies. ${ }^{9}$ By contrast, the changing role of the chieftaincy during the 1980 s and the effects on the popular legitimacy of the 'tribal' hierarchies have scarcely been explored. As the chiefs lost many of their previous responsibilities and proved largely incapable of delivering services to their communities, the burdens imposed by them

8. Ineke van Kessel, "Beyond our Wildest Dreams": the United Democratic Front and the transformation of South Africa' (unpub. Ph.D. thesis, Leiden University, 1995), ch. 4; Izak Niehaus, 'Witchburning and political legitimacy: Continuity and change in Green Valley, Lebowa, 1930-91', Africa, 63, 4 (1993), pp. 498-530; Edwin Ritchken, 'Burning the Herbs: Youth politics and witches in Lebowa', Work in Progress, 48 (July 1987), pp. 17-22.

9. See for example: Jeremey Seekings, 'Quiescence and the transition to confrontation: South African townships 1978-1984' (unpub. D.Phil. thesis, University of Oxford, 1990). 
were felt as increasingly onerous. Grievances centred around 'tribal' levies and tributes, and authoritarian rule.

'Tribal' levies can be raised for special purposes after the chief's council has gained the approval from the formal gathering of adult men. In practice, these meetings were often called during weekdays, thus excluding the migrants from the consultation process. Upon their return to the village, migrants were presented with the bill which the chief and the elder men had decided upon. The special purposes generally include the building of a school, clinic or post office; paying for legal advice in cases involving the chief or the 'tribe'; contributing to his marriage goods, or to the costs of his funeral; procuring the services of the rain-makers. Frequently, the taxes were of more benefit to the chief's private affairs than to the community. Tributes were raised to buy a car for the chief, or to pay his repair bill, to build him a brick house, preferably with two storeys and modern amenities. The more extreme stories of arbitrary chiefly taxes included levies to pay his traffic fines and for nappies for his children. This system of 'taxation without representation' was at the root of many grievances against chieftaincy. The migrants' organization Notpeco (Northern Transvaal People's Congress), a UDF affiliate in the Northern Transvaal, mobilized its following mainly on this issue, by impressing on the migrants that they were entitled to be part of the decision-making process. ${ }^{10}$

Apart from taxation, free labour was also perceived as a form of exploitation. Free labour is exacted mainly from women and schoolchildren. It involves mostly maintenance work on the chief's homestead and work on the 'tribal' land held by the chief. Youth activists frequently mentioned 'tribal' custom as a 'source of oppression'. There are numerous examples of villages where youth activists in the 1980 s demanded open accountability of 'tribal' finances; sometimes they seized control over the school fund. In several cases, chiefs were chased away from their village and in a few villages the chief was actually killed. Faced with these challenges to their authority from different quarters, many chiefs reacted by forming armed vigilantes to combat rebellious youth. Weapons were provided by the bantustan government. The 'tribal' authorities were one of the key pillars of the 'pacification' strategy of the South African army in the Northern Transvaal. From the point of view of UDF activists, chiefs were part and parcel of the repressive status quo.

Village meetings could only be held with permission from the chief. Chiefs generally opposed attempts to establish a civic association, which they rightly perceived as an alternative power structure. Civics had multiplied in the African townships during the first half of the 1980s,

10. van Kessel, 'Beyond our Wildest Dreams', pp. 208-12. 
organizing residents around bread-and-butter issues such as rents, electricity and the costs of bus transport. By virtue of the affiliation of the civics to the UDF, these campaigns around local issues became linked to the nationwide liberation movement. In the second half of the decade, civics made their way to the rural villages, but they were far less effective in the rural context.

The UDF stood for a unitary South Africa, without ethnically-based bantustans. Since the 'tribal' hierarchies had become an integral part of bantustan administrations, it followed that both homeland government and chiefs had to be abolished. The National Working Committee of the UDF resolved in 1986 that 'tribal structures should be replaced with democratic organisations'. ${ }^{11}$ Other UDF publications suggested that short-term alliances with chiefs could be expedient in places where the chief still enjoyed popular support, but the objective in the long run was generally summed up as 'Chiefs must go and the people must run the villages'. ${ }^{2}$

\section{Changing perspectives on chieftaincy: 1987-1996}

Against this background, it is not surprising that the emergence of an ANC-aligned organization of chiefs came as a shock to many UDF and ANC adherents. The formation of the Congress of Traditional Leaders (Contralesa) met with an ambivalent response: Could 'progressive chiefs' be organized to further the liberation struggle? Contralesa had its origins in the battle against independence in KwaNdebele and the resistance in the district of Moutse against incorporation into KwaNdebele. ${ }^{13}$ KwaNdebele, the most recently established bantustan, was scheduled for 'independence' in 1986. Moutse residents feared that the planned excision of their district from Lebowa and the incorporation into KwaNdebele would entail the loss of their South African citizenship. One of the prime movers of the anti-independence camp was Prince Klaas Makhosana Mahlanga of the Ndzundza royal family in KwaNdebele. Along with several other senior leaders, he was expelled from the KwaNdebele Legislative Assembly for his opposition to independence. Klaas Mahlangu and other opponents of independence, many of whom had to flee KwaNdebele in fear of their lives, flocked to Johannesburg looking for help. Now a new problem posed itself to a UDF leadership which by this time was working semi-clandestinely under the State of Emergency.

11. UDF report on the National Working Committee conference, 24 and 25 May 1986.

12. SASPU National, 7, 4 (November-December 1986). For a discussion of the grievances against chieftaincy and youth rebellion, see: Ineke van Kessel, "From Confusion to Lusaka": the youth revolt in Sekhukhuneland', fournal of Southern African Studies, 19, 4 (1993), pp. 593-614.

13. Transvaal Rural Action Committee, 'KwaNdebele-The Struggle against "Independence"', in W. Cobbett and R. Cohen (eds.) Popular Struggles in South Africa (James Currey, London, 1988), pp. 114-35; E. Ritchken, 'The KwaNdebele struggle against Independence', South African Review, 5, pp. 426-45. 
What to do with chiefs who supported a progressive cause, i.e. the anti-independence struggle in the bantustans? Would organizing chiefs serve the purpose of broadening out and further isolating the enemy? The idea was discussed with Samson Ndou, vice-president of the UDF region Southern Transvaal, with Peter Mokaba, president of the South African Youth Congress (SAYCO, the largest UDF affiliate) and several others, including trade unionist Desmond Mahasha, who dipped into the coffers of the General and Allied Workers Union to provide funds to get the new organization started. Fortunately for him, this initiative was later sanctioned by the ANC who 'bailed him out' when he risked losing his job because of misuse of union funds. ${ }^{14}$ Ndou, Mokaba and Mahasha all come from the Northern Transvaal.

Contralesa was launched in September 1987 in Johannesburg, claiming a membership of 38 chiefs and sub-chiefs from KwaNdebele and Moutse. According to its constitution, Contralesa aims to unite all traditional leaders in the country, to fight for the eradication of the bantustan system, to 'school the traditional leaders about the aims of the South African liberation struggle and their role in it', to win back 'the land of our forefathers and share it among those who work it in order to banish famine and land hunger', and to fight for a unitary, non-racial and democratic South Africa. ${ }^{15}$ Contralesa emerged on the political scene couched in the discourse of liberation politics.

The involvement of SAYCO in the launch of Contralesa gave rise to the suspicion that this organization was being formed with the ultimate goal of abolishing the institution of chieftaincy. That suspicion was not unfounded. Some of the activists involved in the formation of Contralesa were indeed motivated by the belief that there was no place for chiefs in the classless society they were striving for. In the meantime however, harnessing chiefs to the progressive cause would prevent them from subverting the struggle. Heeding the lessons from Angola and Mozambique, where 'the destabilizing factors such as Unita and Renamo found fertile ground in the disillusionment of rural people', it was imperative to 'organise and unite all traditional leaders of our country and to refrain from aligning (sic) ourselves with any particular oppressive system today or in the future'. ${ }^{16}$

While the formation of Contralesa as a partner in the liberation movement was shocking news to many activists inside South Africa, the ANC was quick to give its blessing. In February 1988, a Contralesa deputation visited Lusaka to meet an ANC delegation headed by secretary-general Alfred Nzo. ANC, UDF and SAYCO all hailed the 'heroic role' which

14. Interview with Desmond Mahasha, Mohlaletse, 23 September 1990.

15. Race Relations Survey 1987-1988 (Institute of Race Relations, Johannesburg, 1988), p. 922.

16. Contralesa Newsletter, no. 1, n.d. (1990). 
chiefs had played in the past against the forces of colonialism, pointed at the significant role of the chiefs in the early years of the ANC and welcomed the 'chiefs coming back to the people'. ${ }^{17}$ It was, in part, the experience of exile which had prepared the ANC for a fresh look at the future position of chiefs. The spectre to be avoided was Mozambique, where Renamo had found fertile recruiting ground among a rural aristocracy which was thoroughly alienated by the rule of marxist-inspired youngsters from town, representing the ruling Frelimo government.

But it was perhaps the intractable Buthelezi and his Inkatha movement which carried most force of persuasion. From the mid-1980s, a low intensity civil war raged between Inkatha and the UDF in Natal, pitting traditionalists and rural villagers against militant youth intoxicated with the belief in impending revolution. In 1990, when Inkatha transformed itself into a nationwide political party, the Inkatha Freedom Party, violent conflict spread to the townships of the Witwatersrand. Buthelezi and Inkatha benefited from the active support of the South African security forces in this battle against their common enemy. But unlike other bantustan rulers, he also had a distinct powerbase of his own. Therefore, Buthelezi could not so easily be dismissed as a puppet of the apartheid regime. The Inkatha leader offers a prime example of a successful straddling technique: while skilfully manipulating the appeal of tradition and Zulu identity in his home base, he also proved an expert player in the politics of the wider world. In order to contest Inkatha's claim to the sole guardianship of Zulu tradition, the ANC in 1992 made a conscious decision to enter the political arena in Natal on Inkatha's terms. ${ }^{18}$ The discourse of development and non-racialism was unlikely to woo Zulu traditionalists. In the battle for the Zulu nation, the ANC attempted to 'out-Zulu' its rival when paying respect to Zulu traditions which included of course royalty and chieftaincy. Control over the guardianship of Zulu tradition (presented as the soul of Zulu nation) is a central theme in the conflict between ANC and Inkatha in KwaZulu-Natal, but also in the tug of war between King Goodwill Zwelithini and Chief Mangosuthu Buthelezi.

Constitutional guarantees for the Zulu kingdom were made into an almost insurmountable stumbling block in the run-up to the 1994 elections, South Africa's first ever elections run on the principle of 'one man, one vote'. But subsequently the king has broken ranks with Buthelezi. Liberated from Buthelezi's control over the purse strings - in the new dispensation the king would be paid by the central government-Zwelithini became a fervent advocate of the non-partisan nature of the office of

17. Thando Zuma, 'The role of the Chiefs in the struggle for liberation', African Communist, 121 (1990), pp. 65-76.

18. Courtney Jung, 'Understanding Zulu identity', Indicator $S A, 13,2$ (1996), pp. 47-55. 
traditional leader. ${ }^{19}$ Meanwhile, Buthelezi had himself appointed as chairman of the House of Traditional Leaders in KwaZulu-Natal. The king's royal council is of the opinion that the king himself should preside over the House. The dispute has been brought before the South African Constitutional Court.

KwaZulu/Natal obviously is a special case. But towards the end of the 1980 s, it seemed that a similar rural reaction as in Natal was not beyond the imagination in the case of other bantustan elites who in tandem with the South African security forces were largely succeeding in suppressing the youth revolt in the homelands. In addition, the ANC was in need of a broader support base. Militant youth had alienated not only the tribal hierarchies, but also large sections of the adult population in the villages. With a military victory of the liberation forces becoming ever more unlikely, ANC strategists began to focus on a negotiated settlement. A negotiated transfer of power would have to be effected through elections. With the promise of delivering their 'block vote', chiefs assumed a new role: no longer relics of a feudal past, but strategic allies in the conquest of state power. As chief Mhlabunzima Maphumulo, a Zulu chief who was prominent in Contralesa, stated in 1990: 'Once a chief has identified himself with us, then we know that the whole tribe or the majority of the people in that area are now with the progressive forces'. ${ }^{20}$

After the unbanning of the ANC in 1990, Contralesa's membership increased dramatically. Its main powerbase was in the bantustans of the Northern Transvaal. Many chiefs began to perceive Contralesa as the best forum to safeguard their interests under a future ANC-led government. From the ANC's point of view, wooing chiefs made political sense. One of the ANC's major concerns in 1990-91 was to prevent the emergence of a National Party-led alliance, in which bantustan leaders and officials, and chiefs would provide the rural support base. In the 1994 elections, the Northern Transvaal proved to be the most solid ANC bastion of all nine provinces. But in 1990-91, this was by no means a foregone conclusion.

In 1990, Contralesa was regarded as an important rural partner in the ANC's strategy to 'isolate De Klerk' by drawing all kinds of disparate forces into a broad alliance under ANC guidance. Chiefs were seen as constituting part of the middle ground between the ANC and the National Party government, hanging in the balance from where they could swing either way. The ANC leadership experienced great difficulty when trying to convince rural youths of the wisdom of this policy. The antagonism was

19. See for example: Deborah Ewing, 'The cause of the King', Leadership, 14, 2 (June 1995). 20. Catherine Payze, 'The elimination of political opponents: the Maphumulo assassination', in A. Minnaar et al. (eds.), Patterns of Violence: case studies of conflict in Natal (Human Sciences Research Council, Pretoria, 1992), pp. 247-58. Maphumulo was assassinated in 1991. 
not limited to youths only. The prospect of the ANC being swamped with yesterdays enemies elicited much criticism from old guard ANC activists, intellectuals and ordinary rank and file members. One bastion of opposition was the civic movement, now nationwide organized under the umbrella of the South African National Civic Organisation (SANCO). Antagonism between civics and chiefs was particularly pronounced in the Eastern Cape. The issue equally served to accentuate the centreperiphery dichotomy: the strategy to win over chiefs and bantustan leaders was devised in the ANC head office in Johannesburg, where Nelson Mandela was known to be a particularly keen advocate of this rapprochement. The picture of venerated ANC leaders wining and dining with bantustan leaders and paying homage to chiefs was thoroughly upsetting for rural activists.

The issues at stake: how do chiefs fit in a non-sexist, non-racial democracy?

Like other stakeholders, chiefs negotiated their entry in the New South Africa in the series of constitutional negotiations which began in late 1991. Even if it rarely became front page news, the issue of traditional leadership posed certain fundamental questions which still prove difficult to tackle. The institution of chieftainship is not in accord with the precepts of democracy in its late twentieth century version. Chiefs are not elected, but hereditary. Secondly, chiefs are mostly men, which goes against the principles of non-sexism. Thirdly, only Africans can become chiefs, which goes against the grain of having a non-racial society. Fourthly, chieftaincy serves to accentuate the forces of ethnicity, which had become thoroughly discredited in the apartheid years when it was used as the organizing principle in the divide and rule strategy of ethnic homelands. ${ }^{21}$ In the popular mind, chieftaincy was equated with 'tribalism' which could divide the African majority and derail the process of democratization and nation-building. If chiefs remained dependent on government patronage as in colonial times and the apartheid years, they could be easily manipulated by the government of the day. How to determine which chiefs were 'authentic' traditional leaders rather than creations of apartheid ethnographers and bantustan regimes? How far would their jurisdiction hold? Would it cover the migrants living in town? Would individuals be free to choose whether they wanted customary law to be applicable? What was the potential of chiefs as agents of rural development? Should they continue to control communal lands? Who should pay the chiefs: the national government, the province, or his subjects?

21. J. C. Bekker, 'The role of chiefs in a future South African constitutional dispensation', in R. S. Ndou and Essy M. Letsoalo (eds.), The Future of the Institution of Hereditary Rule and Customary Law in South Africa (Marshalltown, no publisher, 1994), p. 77. 
Writing in 1992, the ANC's constitutional expert Albie Sachs gave a highly optimistic assessment of the developmental potential of chiefs: 'Traditional leaders are entitled to a dignified and respected role which enables them to take their place in and make their contribution towards building a new democratic South Africa. Their position in the new constitutional order should be such as to permit them to recapture the prestige which was undermined by colonialism, segregation and apartheid.' The objective, Sachs believed, was not so much to democratize traditional institutions as to constitutionalize them. ${ }^{22}$ This is a far cry from Mbeki, Mzala and the classless society envisaged by activists in the 1980s. How are traditional authorities being 'constitutionalized'?

\section{The 'constitutionalization' of traditional leaders.}

Both the interim constitution and the final constitution provide for the recognition of traditional leaders. A clause in the interim constitution specified that all traditional leaders who were functioning in this capacity at the time when the negotiations were concluded will be recognized as such for the duration of this five year transition period. ${ }^{23}$ The recognition of traditional leadership and indigenous law was enshrined in the constitutional principles which guided the deliberations in the Constitutional Assembly. This recognition would among other things entail the right to a salary paid by the government, to adjudicate certain disputes according to customary law and to representation at various levels of government. Provision is made for the establishment of a House of Traditional Leaders in each province which has traditional leaders and the establishment of a Council of Traditional Leaders at national level. Each House of Traditional Leaders is empowered to advise its provincial legislature on matters relating to indigenous law, tradition and custom, while the Council of Traditional Leaders is empowered to advise the national government on the same matters. These bodies do not have the power to reject or amend legislation. They are only entitled to advise the legislators. At most they can delay the passing of a bill by 60 days. ${ }^{24}$

Nevertheless, there are some notable differences between the firm guarantees defined in the interim constitution and the hesitant phrasing of the final version signed by President Mandela on 10 December 1996. Whilst the interim constitution explicitly states that there shall be Provincial Houses and a National Council of Traditional Leaders, its successor is more hesitant: national legislation may establish these institutions but there is no obligation to do so. One reason for the watering down of this clause

22. Albie Sachs, Advancing Human Rights in South Africa (Oxford University Press, Cape Town, 1992), pp. 77-8.

23. S181.1 Interim Constitution and S 26 of the transitional arrangements (schedule VI) in the definite Constitution as adopted by the Constitutional Assembly on 11 October 1996 and signed by President Mandela on 10 December 1996.

24. Survey of Race Relations 1993-1994, pp. 556-57. 
might be the problems experienced thus far with the formation of these Houses. By December 1996, Houses of Traditional Leaders had been established in only four of the six provinces which have state-appointed traditional leaders: KwaZulu/Natal, Northwest, Mpumalanga and the Free State. The process in the Eastern Cape remained deadlocked by the conflict between chiefs and civics, while in the Northern Province the issue hinged on the mode of representation of the chiefs. Gauteng, the Northern Cape and the Western Cape are not destined to have a House of Traditional Leaders as these provinces do not incorporate former bantustans. Since not all Provincial Houses have been constituted, it proved impossible to proceed towards the establishment of the National Council of Traditional Leaders. The Houses have to elect the members of the National Council. Legislation enabling the installation of a National Council was therefore withdrawn from parliament in October 1996.

A clause in both the interim and the final constitution allows traditional leaders to adjudicate disputes according to customary law. The issue of customary law became a subject of fierce debate in the constitutional negotiations, pitting women's organizations against Contralesa. At one point the rural women's movement threatened to boycott the 1994 elections if the ANC would abandon its non-sexist principles in order to placate chiefs. The Bill of Rights provides for equality before the law and to equal protection of the law. But in many systems of customary law, African women fall under the guardianship of their father or, after marriage, their husband. They have no contractual capacity without the consent of their guardian and are not allowed to appear in court without the assistance of their guardian. They are excluded from the political process of the tribe and are sometimes precluded from obtaining land rights. This minority status of African rural women was codified in the Native Administration Act of 1927. ${ }^{25}$ How to reconcile customary law with the equality clause in the constitution? Against the argument that the low status of women under customary law was out of step with the basic tenets of contemporary human rights law, chiefs countered that 'our culture cannot be outmoded'. ${ }^{26}$ Customary law however has proved to be capable of adapting to change. These systems now face the major challenge of adapting to the equality clause in the constitution, which will prevail over customary law. According to a 1995 survey, the majority of South Africans approve the institution of traditional leadership but favour

25. S11 (3)(b) NAA: 'A Black woman (excluding a black woman who permanently resides in the province of Natal) who is a partner in a customary union and who is living with her husband, shall be deemed to be a minor and her husband shall be deemed to be her guardian.'

26. Padi Matlala: 'Can Chiefs change?', New Ground (Spring 1993), pp. 2-4. 
more female participation in traditional authorities, including the customary courts. ${ }^{27}$ These courts deal with minor crimes, family law and dispute settlement and thus relieve the state magistrature of a substantial workload.

The most thorny issue perhaps is the role of chiefs in local government. This was the central issue prompting the postponement of the local elections in KwaZulu Natal: while the ANC believed that chiefs should play some part in local government, Inkatha maintained that chiefs are the local government. The negotiators who produced the Local Government Transition Act were focused on urban areas, where formerly white towns and African townships had to merge into administratively viable units. The homelands lack an appropriate historical precedent of local government and their system of local administration was by no means uniform. The Act applies to rural areas as well, but pays scant attention to the specific characteristics of the former bantustan areas. The result was a momentous confusion at the time of the local elections in November 1995. There was no clarity about the functions of elected and traditional authorities, and therefore a great potential for conflict about the role of the chiefs. ${ }^{28}$ Unresolved for example was the responsibility for the allocation of land, previously one of the prerogatives of traditional leaders. Two modes of representation are possible under a proclamation issued by the government in August 1995. Chiefs can be appointed as ex-officio members of the Transitional Local Council, or they can be represented on this council as an 'interest group'.

In the case of ex-officio members, all the recognized traditional leaders are entitled to a seat on the council. The extent of their powers is, however, unclear. In most provinces, the ex-officio members have the same rights as the elected members, including the right to vote on issues before the council. In the Northern Province, the provincial government decided against this, because in numerous cases chiefs could have outvoted the elected members. It was never intended that chiefs would outnumber elected members, but in several parts of the former bantustans this happened to be the case.

But the proclamation also allows for another model: chiefs would then be represented as an 'interest group' along with women, farm-workers and farm-owners. Each interest group would occupy not more than ten percent of the seats on the Transitional Representative Council. The total percentage of 'representatives of interest groups' could not exceed 20 percent of the number of seats. The traditional leaders were up in arms against this model. They resented being put in the same category as

27. Nirmala Pillay and Cas Prinsloo, 'Tradition in Transition?: exploring the role of traditional authorities', Social Update (Human Sciences Research Council, Pretoria, 1995). 28. Alistair McIntosh and Anne Vaughan, 'Towards a system of rural local government for the Northern Transvaal' (Development Bank of South Africa, 1994), p. 9. 
rural women..$^{29}$ And they objected to their minority position on an elected council. Contralesa chairman Patekile Holomisa protested that 'this will put the position of the traditional leaders in the hands of the very people who are so hostile to us', ${ }^{30}$ an assertion which casts some doubt on the claims of the chiefs that they enjoy wide popular legitimacy. He threatened to take the government to court. One other objection centred around the notion of representation as such. It was argued that one cannot expect one traditional leader to represent another. ${ }^{31}$

But the chiefs were equally unhappy with the ex-officio status, if this meant that they had fewer rights than the elected councillors. If the subjects of the chief are more powerful than the chief himself, a status problem poses itself. The definitive constitution leaves out all reference to the ex-officio membership of traditional leaders in local government bodies and confines itself to the non-committal statement that national legislation may provide a role for traditional leadership as an institution at local level on matters affecting local communities. ${ }^{32}$ While the position of traditional leaders who are ex-officio members of local government is guaranteed until April 1999, it seems likely that their official role will diminish after this date. ${ }^{33}$ Bridging legislation on local government, for instance, makes no mention of the chiefs. ${ }^{34}$

The reference to national legislation in this constitutional clause is noteworthy. In the much contested balance of power between the provincial and central legislatures, traditional leadership as well as local government fall under the exclusive legislative competence of the provinces. But the power given in this respect to provinces such as KwaZulu/Natal was evidently perceived by the ANC-dominated government as sufficiently threatening to overrule it by constitution. At the time of writing, the issue of the representation of traditional leaders in local government in KwaZulu/Natal had not been resolved. Traditional leaders continue to form the primary form of rural local government. On an intermediate level, the province has seven elected regional councils, on which chiefs are represented.

Equally controversial is the control over the purse strings: who pays the chief? The Remuneration of Traditional Leaders Act, passed by the South African parliament in July 1995, makes payment of the salaries a responsibility of the central government. The provinces, up till now responsible for footing the bill, may decide to add extra allowances, for

29. Weekly Mail and Guardian, 18-24 August 1995.

30. The Star, 23 August 1995.

31. Unpublished report by Barbara Oomen of a meeting with officials of the Department of Constitutional Development, 17 November 1995.

32. $\mathrm{S} 212.1$ of the definite constitution.

33. S.26 of the transitional arrangements (Schedule VI) in the definite constitution. Before

1999, the ex-officio membership can only be terminated by an Act of Parliament.

34. Draft Further Regulation of Local Government Bill, notice 1010 of 1996. 
example for attending sessions of the House of Traditional Leaders. The transfer of the control over salaries from the provinces to the central government is obviously meant to loosen Inkatha'a grip on the Zulu chiefs. While Inkatha argued that chieftaincy matters fall under the competence of the provincial legislator, the central government stated that this, on the contrary, was one of those exceptional instances which called for uniform standards. The Inkatha-dominated provincial government of KwaZulu/Natal reacted furiously and passed legislation prohibiting traditional leaders (including the King!) to receive remuneration from the central government. ${ }^{35}$ The case was put before the Constitutional Court, which ruled in July 1996 that this legislation was indeed within the competence of the province and that this prohibition was not inconsistent with the Constitution. ${ }^{36}$ By the end of 1996, the legislation on remuneration had not yet been implemented, mainly because the Commission on the Remuneration of Representatives had not yet come up with the recommendations on the payment of traditional leaders. It is expected that the Commission will recommend uniform payment scales for the same categories of traditional leaders all over the country. Presently enormous differences in salaries and benefits continue to exist between the provinces. In the Northern Province, a chief receives about 50,000 rand annually, while his colleague in the neighbouring North West Province has to be satisfied with an average 6,000 rand. ${ }^{37}$

As a corollary of new rules and new paymasters, it has to be established who will benefit from the Remuneration Act. Who are the legitimate chiefs' as distinct from the creations of the apartheid state and the illegitimate usurpers of power? South Africa seems set for a new round in the familiar game of British colonial politics: 'Find the Chief'.

\section{'Find the Chief'}

In the past, this issue was handled by the Department of Native Affairs. Since 1926, South African government ethnographers have collected evidence and compiled family trees of some 800 'tribes'. This work used to be the preserve of Afrikaner ethnographers, who until now still dominate the scene in 'native affairs'. Their collections were mainly used in succession matters. But legitimacy and expediency do not always coincide: numerous 'true' leaders have been disinherited while compliant marionettes were elevated to higher ranks. In nearly every discussion on chieftaincy, the issue keeps popping up: who are the chiefs? And who decides?

35. The payment of Salaries, Allowances and other Privileges to the Ingonyama Amendment Bill of 1995 and the KwaZulu/Natal Amakhosi and Iziphakanyiswa Amendment Bill of 1995. 36. Case CCT1/96 before the Constitutional Court, heard on 21 May 1996 and judgment delivered on 5 July 1996.

37. Barbara Oomen, 'Talking Tradition: the position and portrayal of traditional leaders in present-day South Africa' (unpub. MA thesis, University of Amsterdam, 1996), p. 37. 
The answers vary. Contralesa has called for an independent commission of inquiry to sort out the issue 'once and for all'. ${ }^{38}$ The Constitutional Assembly, when dealing with calls to establish the authenticity of chiefs, decided that this was the responsibility of the Department of Justice. ${ }^{39}$ The Department of Constitutional Affairs also handles chieftaincy issues. Until new rules are adopted, the Native Administration Act (1927) continues to apply: the state president has the final say over who is appointed a traditional leader. Similarly, the president can define the duties, powers, privileges and conditions of service of traditional leaders thus appointed and depose leaders when he deems this necessary. ${ }^{40}$ What does all of this mean in real life in rural South Africa? For a glimpse of the practical implications of new laws and old institutions, we look in somewhat more detail at the situation in the Northern Province, formerly the Northern Transvaal.

\section{The Northern Province: old leaders and new masters}

The Northern Transvaal is one of the most rural parts of South Africa. This was the heartland of conservative Afrikanerdom, dominated not by the National Party, but by the Conservative Party, the Afrikaner Weerstandsbeweging and the latest addition to Afrikaner political parties, the Freedom Front. In the 1994 general elections, the ANC scored a massive victory. Among the nine provinces, the Northern Transvaal proved to be the most solid ANC bastion. In line with national politics, the ANC followed a conciliatory approach and included a representative of the Freedom Front in the provincial cabinet. But for Black South Africans, the Northern Province is a de facto one-party state: the ANC is the only game 'in town'. This means that conflicting interests are not represented by different parties, but have to be accommodated within the ANC. Phrased in the discourse of liberation politics the 'contested terrain' is now within the ANC. Civil servants, chiefs, youths, women, black business and other interest groups all seek ANC patronage. One major headache for the government of the Northern Province was the incorporation of three former bantustans: Venda, Ganzankulu (destined for the South African Tsonga/Shangaan; the majority of the Shangaan live on the other side of the border in Mozambique) and Lebowa (Northern BaSotho). The government inherited the costly legacy of Grand Apartheid. The bureaucracies of the former bantustans, reputed to be inefficient and corrupt, had to be absorbed in the new provincial administration. Traditional leaders, until recently maligned as the faithful servants of the apartheid government and the bantustan despots, had to be

38. Weekly Mail, 23-29 June 1995.

39. Constitutional Talk, 8 September 1995.

40. S2 Native Administration Act 38 of 1927. 
incorporated in provincial and local government and in the ANC's ambitious five-year development plan, the Reconstruction and Development Programme (RDP). Former enemies-chiefs, youth activists, civic associations-all became dependent on ANC patronage. This part explores how traditional leaders manoeuvre in this new game, forging new alliances in order to safeguard their position. ${ }^{41}$

Responsibility for policy vis-à-vis chiefs initially rested with the Commissioner for Traditional Authorities, a short-lived position which was abolished in 1996 as a result of an internal rearrangement of the provincial administration. The first and only Commissioner, Benny Boshielo, who also served as deputy secretary of the ANC in the Northern Province, was rather uncomfortable with this job. A young ANC activist who spent considerable time abroad studying in Amsterdam, he was not at all convinced that chiefs enjoyed broad popular support. $\mathrm{He}$ basically believed that the institution was a waste of time and money. In his view, the ANC had rehabilitated the chiefs and given them a new role in post-apartheid South Africa. But in turn, the chiefs were most ungrateful. Some chiefs still did not allow civic associations in their village. Some had obstructed the local elections by contesting the delimitation of electoral districts in court. In several places, chiefs called for a boycott of the local elections. Some propped up their rule with armed vigilantes and refused to be disarmed. In some villages, chiefs managed to gain control over job creation under the RDP. Companies wanting to recruit labour for RDP projects were told to report to the chief's kraal. This provided the chief with a crucial network of patronage: jobs are the highest priority in any rural village. Boshielo tried to remove chiefly control over employment. With the election of new local councils in November 1995, an alternative network had been established to dispense jobs and contracts.

Interviewed in 1995, the Commissioner for Traditional Authorities sounded thoroughly frustrated with the lack of ANC policy on the issue of chieftaincy. 'The ANC must make up its mind: do we want chiefs or not? If yes, then we must make them effective. If no, then we must do away with them.' His days were occupied with 'endless bickering and protocol'. The issue of the provincial House of Traditional Leaders was still unresolved (and remains unresolved at the time of writing). $\mathrm{He}$ handled numerous succession disputes and received scores of people who contested the legitimacy of 'their' chief. His newly created position gave rise to another question: how legitimate was the youthful Commissioner for

41. Most of the material for this section was gathered during a visit by Ineke van Kessel to Pietersburg and Sekhukhuneland at the time of the local elections in November 1995 and by Barbara Oomen later that same month. Interviews were conducted with the Commissioner for Traditional Authorities in Pietersburg and with acting paramount chief $\mathrm{K}$. K. Sekhukhune in Mohlaletse. 
Traditional Authorities in the eyes of the chiefs? Chiefs obviously tried various avenues to further their interests sometimes through the Commissioner, but they could also try to circumvent him in order to pull strings at national level in the ANC.

Boshielo controlled a substantial budget of R108 million, which was more than many other provincial departments. Chiefs were paid by the provincial government, rather to the chagrin of Boshielo who believed that chiefs ought to be maintained by their people. Why, he asked, should chiefs be maintained at the taxpayers' expense? Nevertheless, all 193 traditional leaders in the Northern Province received a salary of R46,000 annually, plus R9,000 to run their office and a bakkie (a van). After the administrative shake-up, traditional affairs became the responsibility of the provincial Department of Local Government. The Commissioner was equally critical of the proposed House of Traditional Leaders, which he regarded as a waste of taxpayers' money. The chiefs most likely were expecting extra allowances for attending meetings, but Boshielo was determined to underplay the importance of this House and to limit expenditures. He was not unhappy with the delays in constituting the House of Traditional Leaders: up till the end of 1995, the savings were adequate for the construction of an extra 60 school class rooms.

The dispute regarding the House of Traditional Leaders hinged on the mode of representation. The provincial government had allocated the 36 seats on the basis of equal representation of 'cultural groups', one third each for the Venda, Shangaan and Sotho chiefs. But the Sotho chiefs campaigned for a system of proportional representation: 'One Chief, One Vote'. This would make them the dominant group in the House. Lebowa, the former bantustan for the Northern BaSotho, had 153 chiefs, while Venda had only 28 and Gazankulu 38. While the Commissioner waited for the chiefs to produce a compromise, the chiefs were waiting for the Commissioner to come up with a solution. The issue was potentially divisive, as passions could be mobilized along ethnic lines. Already the paramount chief of Sekhukhuneland, a part of former Lebowa, was expressing doubts whether the Shangaan chiefs ought to be represented at all. After all, 'they came only yesterday, they are from Mozambique. They did not even have chiefs, and now they are claiming seats in the House of Traditional Leaders', ${ }^{42}$ He blamed the delay on the alleged dominance of Venda and Shangaan people in the provincial government.

Naturally, the Venda and Shangaan chiefs favoured the system of equal representation. Moreover, they questioned the legitimacy of this multitude of Sotho chiefs: surely, these could not be all 'authentic' traditional leaders? As we have seen, many chieftaincies were indeed created with the

42. Interview with Acting Paramount Chief K. K. Sekhukhune, November 1995, Mohlaletse. 
introduction of the Bantustan authorities. In Venda, a clean-up of these newly created chiefs had already been carried out in 1990, when the previously quiescent homeland went through a period of turmoil. Therefore, the number of Venda chiefs was by 1995 substantially lower than that of the Sotho chiefs.

Commissioner Boshielo had instituted a Commission of Inquiry charged with an investigation into the authenticity of the Northern Province's chiefs. By November 1995, the commissioner had received 406 claims to chiefly status, but also numerous submissions in which the legitimacy of chiefs was being challenged. According to Boshielo, many people welcomed the installation of the commission in the hope that their chiefs would be deposed. The scale of the investigation by the Commission was ambitious: the cut-off date for its historical research was 1927, the date of the introduction of the Native Administration Act. Other important vetting points were 1951 (introduction of the Bantu Authorities Act) and 1971 (Bantu Homelands Constitution Act). Boshielo expected that this inquiry would result in a reduction of the number of chiefs by about 40 percent.

The installation of this commission had the full support of the acting paramount chief of Sekhukhuneland, K. K. Sekhukhune. But his motives were rather different from those of Benny Boshielo or the 'commoners' who welcomed the weeding out of illegitimate chiefs. K. K. Sekhukhune believed that this purge would serve to restore 'tradition', that is the power of the paramountcy. If the creatures of bantustan rule were swept aside, the remaining 'legitimate' chiefs would be accountable to the paramountcy, as it was before the introduction of Bantustan Authorities. A historical injustice would be undone: the BaPedi Kingdom would be recreated. This was definitely not the intention of the Commissioner of Traditional Authorities in Pietersburg. The status of the heir to the BaPedi kingdom was also being challenged from other sides. If the $\mathrm{Zulu}$ and perhaps the BaPedi can have a king, why should other peoples not have a king? Venda and Shangaan chiefs also submitted claims to paramountcy status. After all, king Goodwill Zwelithini's annual salary was in the range of R350,000R400,000, plus benefits. That was almost tenfold the salary of an ordinary Northern Province chief.

\section{Royal blood versus $A N C$ patronage}

However, the overriding concern in the life of K. K. Sekhukhune (commonly known as $\mathrm{KK}$ ) over the years was not the House of Traditional Leaders or the claims from upstart Shangaan or Venda chiefs. His one enduring torment was his half-brother Rhyne Thulare who also claimed the right to the BaPedi throne. When the throne vacated in the 1980 s, Rhyne made it known that he was not a candidate. KK was duly installed as 
acting paramount chief. The undisputed incumbent is KK's eldest son who at the time was still an infant. Later Rhyne changed his mind and staked a claim to the paramountcy. His claim was supported by the then prime minister of Lebowa, Nelson Ramodike. On the other side, KK's alliances were geared towards the ANC. He was on good terms with the UDF leadership and he was one of the early members of Contralesa. During the 1994 elections he campaigned openly for the ANC. He won a court case in which Rhyne challenged his right to the throne. The Lebowa government appealed to the Appellate Division of the South African Supreme Court, but KK won again, at great financial expense to his 'tribe' and himself. But his half-brother did not give up. The Lebowa government created a new 'tribe', the Bapedi Thulare, and installed Rhyne as its chief. $\mathrm{KK}$ went to court to challenge this decision and again won his case. The provincial government-by now Lebowa had ceased to exist and the ANC formed the provincial government-had to depose Rhyne. The Commissioner for Traditional Authorities tried to arrange a discussion between the two claimants, but KK refused. Commissioner Boshielo tried again and managed to assemble two delegations from each side in a Pietersburg hotel in an attempt to solve the issue in a consultation of the elders. But the elders from each side refused to recognize the authority of the elders on the side of the rival. In this impasse, the provincial government recognized $\mathrm{KK}$ as the acting paramount chief, who would also be entitled to a seat in the House of Traditional Leaders.

Rhyne was still not outmanoeuvred. He now shifted patronage. His previous alliance with the homeland government of Nelson Ramodike was utterly useless under the new masters of the ANC. Rhyne switched to playing the ANC card. He called on his uncle John Nkadimeng, an old guard ANC activist from Sekhukhuneland who rose to prominence during the long years in exile. Nkadimeng arranged an audience for Rhyne with Nelson Mandela. When Rhyne received this prestigious invitation, he replied that he had no transport. Mandela, known to be a great admirer of the institution of chieftaincy, saw to it that Rhyne was given a Mercedes Benz. All of this has of course infuriated KK Sekhukhune. As KK explained in an interview, there are three attributes for recognition as a chief: a car, an office and an account number. Presumably, these requirements come in addition to a genealogical claim. With the donation of the Mercedes by the State President himself, Rhyne had gained a strategic asset. In addition, Rhyne had sidelined the provincial government and taken his case right to the presidential office. This put $\mathrm{KK}$ at a disadvantage: while he had access to the provincial government, he had no direct access to the central government. In order to keep up with Rhyne, he also tried to arrange an audience with Mandela. When he did not succeed, he 
had to satisfy himself with talks with the minister of constitutional affairs Roelf Meyer and with deputy minister Mohammed Valli Moosa. The appointment, in late 1995, of John Nkadimeng as ambassador to Cuba must have come as a great relief to KK Sekhukhune. KK resented the interventions by the politicians after the court had clearly validated his claims. He talked of suing the ANC government for contempt of court, but at the same time he remained keenly aware that he could not afford to alienate the ANC.

The trials and tribulations of KK Sekhukhune are of interest because they reveal how the paramount chief attempted to safeguard his position by combining the resources of tradition, modernity and liberation politics. The dispute with Rhyne was fought with arguments invoking tradition: 'my royal blood is thicker than his'. But his good standing with the ANC was-at least in a certain period-also helpful in propping up his position. In the dispute about the composition of the House of Traditional Leaders, KK's arguments were borrowed from the discourse of liberation politics: 'One Chief, One Vote: that is our democratic right'.

\section{The aftermath of the elections}

With the national and local elections over and with no substantial rival to contest its hegemony in its African constituency outside of KwaZulu/Natal, the ANC seemed to lose much of its earlier enthusiasm for traditional leaders. One reason was the growing divide between the ANC and Contralesa, whose executive had been taken over by a faction headed by Chief Patekile Holomisa and Winnie Mandela, both from the Transkei. Chairman Holomisa and treasurer Winnie Mandela, both known for their maverick politics, turned the organization into their personal power-base, thus alienating most of their chiefly constituency in the North. Not only did Holomisa liaise with IFP-aligned chiefs in KwaZulu/Natal, he also joined them in calling for a boycott of the local government elections.

But it was probably these local government elections themselves that engendered the more critical stance towards traditional leadership which inspired the more recent legislation. In 1994, with two elections ahead and the traditional leaders ruling an estimated 40 percent of the population, their role in delivering the rural vote could not be underestimated. In his speeches, Mandela was most accommodating towards chiefs. After his release from prison in 1990, Mandela explicitly addressed them: 'I greet the traditional leaders of our country-many of you continue to walk in the footsteps of great heroes like Hintsa and Sekhukhune'. ${ }^{43}$ After a meeting with traditional leaders, Mandela stated that 'the role and place of traditional leaders in our society has in the past 43. Nelson Mandela's address to a rally in Cape Town on his release from prison, 11 February 1990: http:/www.anc.org.za/ancdocs/speeches/release.html. 
been systematically undermined by successive racist regimes which sought to reduce their role to enforce repugnant apartheid politics. Today's meeting should be seen in the context of restoring traditional leaders to their rightful place in society. ${ }^{\prime 4}$

The question of how to reconcile such a restoration with the introduction of elected local government bodies in rural South Africa was not addressed until after the local elections were over. In his first firm statement on the issue since the elections, Mandela asserted in early 1996 that 'we want to advise the traditional leaders in our country to abandon the illusion that there can ever emerge a constitutional settlement which grants them powers that would compromise the fundamental objective of a genuine democracy in which the legislature and the executive at all levels are made up essentially of elected representatives'. ${ }^{45}$

The outcome of the local elections made the ANC more confident that it could win on its own without cumbersome alliances with traditional leaders. Even in KwaZulu/Natal, the ANC did better than anticipated. Thus South Africa's definite constitution is much more non-committal than its predecessor when it comes to defining the position of traditional leaders in post apartheid South Africa. The battle however is far from over. Immediately after the adoption of the constitution, Inkatha, which had boycotted most of the constitutional process, reasserted its demands that traditional leaders be given greater authority in local government. The party threatened to call for a review of the constitution in this respect. ${ }^{45}$ Although Inkatha is most outspoken in its support of the chieftaincy, the view that there is a place for the institution in the New South Africa is fairly widespread. From the submissions to the Constitutional Assembly, it is evident that there is wide acceptance of a continued role for traditional leaders, although positions differ when it comes to defining their powers and duties. In many submissions, it was emphasized that chieftaincy ought to be a non-partisan institution. ${ }^{47}$

\section{Conclusion}

In conclusion, it can be stated that the position of traditional leaders in post apartheid South Africa remains thoroughly ambivalent. The comeback of the chief has been effected with the support of the ANC, but the battle between traditionalists, modernists, African nationalists and communists within the ANC is far from over. In the transition phase, the ANC and the chiefs perceived a mutual benefit in cooperation. By 1995, the honeymoon between ANC and the dominant organization of chiefs,

44. ANC statement on the meeting between president Mandela and traditional leaders, 1995: http://www.anc.org.za/cgi-bin/mfs/01/tradlead.

45. Speech, January 1996. http://www.anc.org.za/ancdocs/history.

46. Weekly Mail and Guardian, 11 October 1996.

47. Oomen, 'Talking Tradition', pp. 139-51. 
Contralesa, had ended. Contralesa itself seemed to be disintegrating due to leadership squabbles, thereby losing its value as interlocutor. Within the ANC, irritation is mounting about excessive demands emanating from traditional authorities and about attempts by a number of chiefs to obstruct the local elections. But although ANC enthusiasm seems to be waning, it is much too early to predict the definitive demise of the chieftaincy. Moreover, traditionalists continue to have a vocal advocate in the Inkatha Freedom Party, although Inkatha thus far has been unable to transcend its Zulu ethnic power base.

The institution of chieftaincy has been transformed by the experience of British colonial rule and subsequently by the apartheid scheme of bantustans. Even during the decades of bantustan rule, the institution, although operating within strict boundaries, allowed at least for some mode of expression of popular concern. Now it faces a new challenge of transformation under the new masters of the ANC government. It remains to be seen whether the elected local councillors succeed in obtaining a wider popular legitimacy. Chiefs have proven that the institution is adaptable to changing times. If traditional leaders are perceived as non-partisan, they can play a valuable role in local communities, e.g. in the sphere of conflict resolution and justice. But if chiefs remain dependent on government patronage, they can easily be manipulated by the government of the day. The central issue remains unresolved: do chiefs derive their legitimacy from state recognition or from popular support? 